\title{
Darkness in Conrad's Heart of Darkness: A Linguistic and Stylistic Analysis
}

\author{
Khalil Hassan Nofal \\ Department of English, Philadelphia University, Jordan
}

\begin{abstract}
This paper is intended to discuss the concept of "darkness" in Joseph Conrad's Heart of Darkness. It incorporates a fairly detailed linguistic and stylistic analysis of the novel in terms of setting, lexical choices and grammatical choices that all indicate mystery, obscurity, murkiness and then darkness. A linguistic and stylistic analysis of the novel is used to show the literary value of the novel. Most specifically all linguistic and stylistic devices used can not only provide a detailed descriptive basis for interpretation of the novel, but also identify the important linguistic features which may not noticed by critics.
\end{abstract}

Index Terms-lexical, grammatical choices, collocation, clefting, short passive, fronting, parenthesis, front-weight, end-weight, complex NP, and complex sentences

\section{INTRODUCTION}

At the heart of the critical linguistic approach is the notion of ideology. Within critical linguistics ideology is generally used to refer to the notion of world view or value system. It refers to the fact that all speakers and writers necessarily operate with assumptions, beliefs and expectations about the universe. The sets of assumptions and beliefs are termed ideologies and, accordingly, all texts can be seen ideological in that they are shaped by, reflect, and hence potentially perpetuate, such value systems or ways of thinking. The terms "ideology" then, when used within critical linguistics refer to the sets of assumptions, beliefs and values which constitute a world view.

Under the critical linguistic approach, the analyst is directed to describe not just the grammatical features of the text but also to consider the socio-cultural contexts. Halliday's approach to linguistic analysis is one which postulates that descriptions and explanations of lexicogrammatical choices and patterns need to focus not only on the words and structures themselves but also on aspects of the social cultural context.

This paper is meant to interpret and analyze Joseph Conrad's "Heart of Darkness" linguistically and stylistically. Joseph Conrad's Heart of Darkness is a very short novel. After its first publication, it is possibly "the most prescribed novel in literature courses in American universities" (Achebe, 1988). That is why it is so popular, but might be rarely linguistically analyzed. The novel is a political text about the colonial power.

The novel is about different issues: navigating by sea in shallow - draft boat, selling, buying and exchanging commodities, investigation of unknown regions, colonization and exploitation, relation between people of different races and origins, besides it is a try to establish a thematic purport or concept while attempting to inspire the curiosity or speculation of imperfect reason.

The dominate idea of civilization "savage" people in wild areas in Africa is the main theme of the novel. Marlow tries to assert that England was one day one of the dark and gloomy places on earth (when the Romans first came to England) and the River Thames was that gate for discovers and messengers of civilization. Besides, Conrad introduces the significance of "light / dark" and "white/black" indicating that "light/white" and "dark/black" are symbols of good and evil. That is, the civilized white people who came from England are good while the black primitive natives are evil and inferior.

Marlow, the storyteller, has a strange belief that he is setting out the journey not to the centre of Africa but to the centre of the earth. This may mean that the journey is set out to the centre of the human spirit, mind and self discovery.

Conrad deals with the dark heart of man. He believes that man is inherently evil cloaked by civilization. The civilized people create morals to mask truth that they do not want to see. See the following signs which were written above the entrances to Nazi concentration camps. See (Dutton 2007:2).

"We come to free you from your ignorance"

"We come to bring you the virtues of civilization"

The following sign shows what the United States of American asserts in Iraq and Afghanistan:

"We come to bring you democracy"

Conrad, as Edward Said put it "allows the readers to see the imperialism as a system "(Said 1994: XXI) "Conrad speaks of colonialism as a religion, calling it a scared fire (Singh 1988: 279).

Conrad exploits the imagery of "black" and "white", "light" and "dark" in a number of ways. Darkness is night, the unknown, the impenetrable, the primitive, the evil.. "White" is ivory, the beautiful luxury of civilized man which is the root of all evil in the darkness. 
While dying, Kurtz affirms the savagery of what he has seen and done. With a mixture of "somber pride, ruthless power, craven terror," and " hopeless despair" he utters his final words "The terror! The terror!" More interestingly, Marlow always frustrates and fascinates people in such a way he keeps asking questions and indicating and stating mysteries but not explaining and revealing.

\section{LINGUISTIC AND STYLISTIC ANALYSIS}

Darkness in the novel can be linguistically and stylistically analyzed as follows:

1. The presentation of episodes of the novel is conveyed in different forms, which indicate darkness:

The novel begins and ends with unnamed narrator. Besides, major places such as Brussels, Belgian Congo, and the River Congo, never appear. The word "Africa" appears only once. Additionally, people are not named, but identified by theirs jobs: the lawyer, Marlow's aunt, the doctor, the accountant, the manager, the director, the clerk, Kurtz's Intended ....etc.

Breaking down is another indicator of darkness. Marlow's boat keeps breaking down "decaying machinery", Kurtz has a mental breakdown, and there are breakdowns in communication: people speak different languages, Marlow tells lies about Kurtz to his fiancée, and "amongst the most frequent content words in the book is the lemma "silence" See (Stabbs: 2005:8). Additionally, Kurt's dying words, "The horror! The horror! are indications of his complete descent into darkness.

2. The setting itself is full of darkness from the very beginning to the very end:

The contrast between light and dark is clear in the theme of setting, the changes in Europeans as they drive farther into the River Congo, and the white man's collapse under the darkness of the River Congo.

The setting of the novel is very critical. All incidents throughout the book indicate darkness. Marlow, for example, tells his story on a boat in so deep darkness that he cannot see his friends, creating a sense of evil surrounding the story. The natives are described as if they were animals not humans:

"Near the same tree two more bundles of acute angles sat with their legs drawn up. One, with his chin propped on his knees stared at nothing, in an intolerable and appalling manner .... others were scattered about in a very pose of contorted collapse, as in some picture of massacre or pestilence".

While leaving the outer station, Marlow makes the rational explanation that if natives came to England and forced all the white men to carry their staff, the Europeans would move away quickly. This statement highlights the brutality of the whites.

- At the very beginning of chapter one, as darkness begins to fall, Marlow suddenly says this was once one of the dark places of the earth. He explains that when the Romans first came to England, it was a great, savage wilderness to them.

- Another important theme that develops in this chapter is Marlow's perception of the environment in the Congo region (which is never named). His first impression of the African coast is seductive and taunting, like some grand enigma.

- Marlow believes that the natives belong to the wilderness, they suffer and die in colonial civilization exactly as the colonials suffer and die in the wilderness.

- At a certain point in chapter two in which Marlow quotes another character besides Marlow, the character is not identified; he is only a voice in the darkness asking him to be civil, as if he is the voice of civilization.

- In chapter three Kurtz was unable to see the candle while dying perhaps because of his inner darkness.

At the end of Marlow's tale, the narrator looks out and sees the Thames which he described at the beginning of the novel as a bright and shining. The river is now covered in gloomy darkness, as if his sight has been clouded by the uneasiness of Marlow's tale.

Now it can be stated that Darkness refers to maps and places of darkness; that have been settled by explores and colonialists. Maps may be symbols of mystery and curiosity by laying out the geography of unknown lands.

The concept of "light" and "dark" corresponds to civilization and savagery. The word "darkness" has its traditional meaning of evil and dread. Darkness corresponds to black color. Marlow describes the natives as "mostly black and naked, moving about like ants"."While in shade," "dark things" seem to stir feebly. There is no difference between dark animals and dark people. Even the rags worn by the natives are described as tails. "Black shapes" crouch on the ground, "creatures" walk on all fours to get a drink from the river.

3. The following lexicogrammatical choices and patterns indicate darkness:

1). Lexical Choices:

- The most frequent words are: "silence", "nightmares'", "trances", "phantoms", "apparititions" and "vision". Watt (1988) argues that there is a lack of clarity in the novel, pointing out that "mist" or "haze" is a persistent image. The following lexical items are frequently used in the novel which indicate darkness:

"absurd, absurdity, absurdity, blurred, bewilderment, bewildering, black shadows of disease and starvation, barren darkness of his heart, blind, craven terror, deaf, darkly, dusk, devil, drowsiness, distances, dark, darkness, fainted, frightful, fog, gloom, gloomly, hidden evil, impenetrable darkness, immense wilderness, invisible wilderness, immense matted jungle, infinite desolation, murkly, mystery, night, profound darkness, unpardonable sin, shadow, shade, smoke, sleepless river, vapour, vague, very grave,, wilderness" 
- Conrad uses repetitive style. He repeatedly uses a large number of words with negative affixes:

"beardless, countless, colorless, dismantled, disappeared, discomposed, dishonor, disfavor, disappear, endless, formidable silence, heartless, hopeless, impossible/impossibility, impenetrable, improbable, impenetrable, impalpable greyness, immortals, implent, inconceivable/inconceivably, incredible, inexplicable, indistinctly, intolerable/intolerably, incomprehensible, incratable, indefinable, inexorable, innumerable, incredible, inappreciable, intolerable/intolerably, inadmissible, indestructible, inestimable, incalculable loss, incontinently, indisputable, inexplicable, inconceivably somber, inexorable time, indisputable right, irresistible, irresistible impression of sorrow, motionless, mysterious life, unearthly, unsound, uneasy/uneasiness, unexpected/unexpectedness/unexpectedly, unexpected regions, unknown, uninterrupted, unstable, unrestrained pain/secrets, unspeakable, unostentatious, uncontrollable, unbounded, unsteady, unscathed, unconnected, unappetizing, unwholesome, unspeakable, unavoidable, unextinguishable, unexplored, uncoiled, unfamiliar, uncongenial, unpleasant, unpardonable, unrecognizable, unreasonably, unnatural, unfathomable, unrestrained grief, uninterrupted shoal, unstable kind of food, unostentatious holes, unapproachable silence, uncontrolled desire, unsteady, sleepless"

In addition to these, there are occurrences of no, not, never, nothing, nobody, nowhere.

- Other major themes are conveyed by repeated lexical contrasts, especially "light" and "dark", "restraint" and "frenzy", "appearance" and "reality". In fashionable modern terminology, Conrad "deconstructs the often taken -forgranted oppositions, white -black and good -bad (Stubbs -2005:9).

- The words "heart", "dark", "darkness", occur throughout the novel, but increase frequently at the very end when the story becomes "too-dark" - "too dark altogether".

- Lexical density (adjectival style): To use lots of adjectives (pre-modifiers, post-modifiers or subject complements) means that the author is semantically enriching the text, to vary, ornate, or flower his style, whereas avoiding adjectives will of course lead to "sparseness and illness". Moreover, Conrad tends to slow the indicant as well as the reader as if he wanted to draw his attention to certain details. Some words occur in recurrent lexico- grammatical patterns. Conrad uses particular grammatical patterns including long strings of adjectives and nouns:

1. "the air was warm, thick, heavy, sluggish"

2. "their glance was guiteless, profound, confident and trustful"

3. "was it superstition, disgust, patience, fear"

4. "joy, fear, sorrow, devotion, vapour, rage, who can tell?"

The adjectives and nouns in the sentences above function as subject complement. The verbs are linking verbs used to relate the adjectives and nouns to their head nouns subjects.

Conrad repeatedly uses nominal groups consisting of an abstract noun plus an adjective with a negative prefix:

5. "the aspect of an unknown planet"

6. "the darkness of an impenetrable night"

7. "the extremity of an impotent despair"

8. "the heart of impenetrable darkness"

9. "the stillness of an implacable force"

It can be easily stated that the abstract head nouns are post- modified by prepositional phrases with head nouns premodified by head adjectives which are pre- fixed with negative markers ( un , in , im ) to denote darkness.

2). Grammatical Choices: Grammatical words denote vagueness and uncertainty:

Conrad uses not just lexical items such as "vague", "fog","mist", and "indistinct" to express doubt, vagueness and uncertainty, but also grammatical function words such as "some", "sometimes", "somebody", "somehow", "kind of", "sort of" all collocate with other expressions of vagueness and uncertainty. The following are illustrative examples:

10. "I don't know - something not quite right".

11. "reminded me of something I had seen - something funny".

12. "the outlines of some sort of building"

13. "seemed somehow to throw a kind of light."

14. "I thought I could see a kind of motion."

Additionally, four - word grammatical sequences are frequently used in the novel to show uncertainty which also indicate darkness: See Senn, 1980;Stampfl,1991.

15. "it seemed to me......;"

16. "as far as I.....;"

17. "as though I had .....;"

18. "as if I were ......;"

19. "with the air of ....;"

20. "the depths of the .....;"

Moreover, the two-word sequence is a pair of grammatical words "of the" which might seem of little interest: of the forest, of the land, of the river, of the earth, of the wilderness, of the world, of the stream.

3). Collocations: Collocations create connotations. The word "grass" is usually associated with death, decay and desolation: "it sprouts through the stones in the city of the dead" (Brussels) and through the bones of "dead men" Stubbs (2005:14). More examples are: 
21. "the grass growing through his rips was "

"enetain blinds, a dead silence, grass sprouting between the stones".

22. "the empty land, through long grass, through burnt grass...... in the ruins of grass walls . Day after day, I've got him . The grass was wet with dew".

The words "glitter", "gleam", "glisten" and "glint" connote things which are ominous and dangerous: the words "glitter", collocates with "dark", "somber" "gloom" and "the infernal stream". The word "gleam" collocates with "blood" and "fire".

Interestingly, the word "existence" collocates with words and phrases like" inscrutable", "deadened", "precarious", "don’t know"," can't tell" .....etc.

23. ".... which is the mistress of his existence and as inscrutable as destiny"

24. "......... man of us out of his little existence. And it moved not. A deadened."

25. "....where - far away - in another existence perhaps. There were moments."

26. "..Keep yours precarious grop on existence. Besides that they had....."

27. "....................... His very existence was improbable inexplicable."

28. "......... in the facts of human existence, I don't know, I can't tell."

Moreover, "wisdom", "truth", "knowledge" collocate with words and phrases like "subtle", "mystery", "riddle", "out of touch" "toil", "surface", (truth), "inner", ("truth"), "glimpsed", ("truth"), "delicate" "witchcraft", "hidden", "conceal", and "irritating pretence". The verb phrases in these clauses undercut a sense of certainty, with verbs and adverbs such as "seemed", "perhaps", "can't say", "I think", "did not bear", and "comes too late".

29. "....... quick glance of unconcerned wisdom. She seemed to know all about them."

30. "................ a nod of mystery and wisdom. "I tell you" he cried."

31. "................ the form of ultimate wisdom, then life is a greater riddle."

32. "............. differences, perhaps all wisdom, and all truth, and all sincerity."

33. " It's queer. How out of touch with truth women are. They live in the world".

34. ".............and invincible like evil or truth, waiting patiently for passing away."

$35 . "$..............that which makes it truth, it's meaning it's subtle and penetrating".

36. "...........................The inner truth is hidden, luckly."

37. ".............. There was surface - truth enough in there things to save."

38. "........appalling face of a glimpsed truth - the strange commingling of desire."

39. ".........perhaps all the wisdom, all truth, and all sincerity, are just composed."

40. "..witchcraft, full of improving knowledge."

41. ".looked with their air of hidden knowledge of patient expectation of unapproachable"

42. "............. can't say. I think knowledge came to him at last".

43. "....seaman - couldn't conceal - knowledge of matters that would affect"

44. "You can hope from it is some knowledge of yourself that comes too late"

45. "...... asked him Mrs. Kurtz's knowledge, however, extensive, did not bear upon."

4). Hyponymy: Conrad uses hyponyms to create a semantically rich and literally meaningful well-packed texts to make the text, i.e., hang together through such a lexical cohesive device. Hyponyms may significantly add to the descriptive and emotive power of Conrad's language. The following is an illustrative example:

46. "black shapes crouched, lay, sat between the trees leaning against the trunks, clinging to the earth, half coming out, half effaced within the dim light, in all the attitudes of pain, abandonment, and despair."

5). Word Order: Modern English is known for its relative lack of morphological inflection and hence its reliance on word order to reflect grammatical relationships. It follows from this that, in English, manipulation of word order is not generally available for conveying other kinds of meaning like foregrounding. There are exceptions, such as the occasional thematization (or fronting) of complements and objects for stylistic effect, but these are marked choices or themes.

English speakers have available to them a range of alternative ways of giving prominence to an element which is not in theme position. There have been neatly summarized by Knowles (1998:107-8):

"English does not ...... possess a high degree of flexibility in the area of element order. To compensate for this, English has developed a small but useful number of devices for allocating appropriate prominence to thematic material."

The chief devices are passivization, clefting (or it clefting), thematization (fronting), parenthesis, front-weight, end-weight, complex noun phrases, complex sentences and hypothetical sentences:

5.1). Short Passive: Short passive / agentless constructions are most commonly and frequently used in the novel and they are used for special discourse functions. They reduce the importance of the agent / doer of an action because the agents may not be known or they cannot be mentioned for legal reasons for example or for other reasons. Short passive becomes a useful device: it allows the objects to be the subject of sentences, hereby giving them topic status. This may lead to haziness and ambiguity and then to darkness. The following are illustrative examples:

47. "The sea and the sky were welded together without a joint."

48. "One of their captains had been killed in a scuffle with the natives." 
49. "I was told the chief's son ....... made a tentative job."

50. "The supernatural had not been touched after he fell."

51. "I had been let into some conspiracy."

52. "Two youths ........ were being piloted over."

53. "I had been represented to the wife of the high dignitary."

54. "After this I got embraced."

Short passive in the above examples are potentially used to obscure or at least de-emphasize the role or involvement of the unmentioned initiating agents. This is to say, the use of short passives means those responsible for the actions/ processes are not brought into the picture and hence are less likely to be negatively assessed. The above short passives, then, may be used to present a given social entity in a more positive light or at least to mitigate negative evaluation of those social actors. In other words, short passivization above enables the removal of actors and hence is another way of avoiding connections in the word which indicates, consequently, darkness.

5.2). It- Clefting: For it-clefting, the information is broken into two clauses, each with its own verb. It- cleft is used to bring particular elements of the clauses into additional focus. These together may lead to ambiguity and haziness. The following are illustrative examples:

55. "It was inconceivable how he had existed, how he had succeeded in getting so far, how he had managed to remain - why he did not instantly disappear."

56. "It was difficult to realize his work was not out there in the luminous estuary."

57. "It did not occur to him that Mr. Kurtz was no idol of mine."

58. "It was ordered I should never betray him - it was written I should be loyal to the nightmare of my choices."

5.3). Thematization: (marked theme): When a clause constituent is moved to initial position, this is called thematic fronting and the fronted element is a marked theme. This is to say, fronting is a matter of marked thematization. It means placing in initial position a clause element which is normally found after the verb to be the departure point. Fronting of circumstances (prepositional phrases) are commonly used in the novel. The following are illustrative examples:

59. "At night I slept, or tied to, on the caoch."

60. "With one hand I felt above my head for the line of the steam-whistle and jerked out screech after screech hurriedly."

5.4). Parenthesis: Parenthesis may hinder the readers to keep their mind far form the departure point (the theme) whatever it is. In other words, the parenthetical clause are used to separate the theme from the rheme, the given (known) information from the new information which also indicate ambiguity and haziness. The following are illustrative examples:

61. "For a long time already he, sitting apart, had been no more to us than a voice."

62. "And when one comes out here, you conceive, it is not to gaze at the moon."

63. "His name, you understand, had not been pronounced one."

64. "He was "that man". The half castle, who, as far as I could see, had conducted a different trip with great prudence and pluck, was invariably alluded to as "that scoundrel".

65. "The retreat, I maintained - and I was right - was caused by the screeching of the steam - whistle."

66. "Some, I heard, got drowned in the surf."

5.5). Front -weight: Front -weight means long and complex (i.e. heavier) elements are placed at the beginning of the clause. This placement may disturb the readers and disable them to keep in their mind complex information from the beginning of the clause as they reach the end. This may result in mystery, obscurity, murkiness and then darkness. The following is an illustrative examples:

67. "A narrow and deserted street in deep shadow, high horses, innumerable windows with venation blinds, a dead silence, grass sprouting between the stones, imposing carriage archways right and left, immense double doors standing ponderously ajar, I slipped through one of these cracks, went up a swept and ungarnished staircase, as arid as a desert, and opened the first door I came to."

5.6). End-weight: The preferred distribution of elements in the clause is called the principle of the end-weight: long and complex (i.e. heavier) elements are placed at the end of the clause. This placement may help the readers to follow the message more easily because they do not have to keep in their mind complex information from the beginning of the clause as they reach the end. But many heavy elements also contain a large amount of information which may disturb the reader. The following is an illustrative example:

68. "But there was in it one river especially, a mighty big river, that you could see on the map, resembling an immense snake uncoiled, with its head in the sea, its body at rest curving afar over a vast country, and its tail lost in the depths of the land."

5.7). Complex Noun Phrases: The basic noun phrase can be expanded with noun modifiers. Premodifiers, like attributive adjectives occur before the head noun, while postmodifiers, like relative clauses, occur following the head noun. The following examples illustrate this point where much of the new information occurs in the modifiers in noun phrases, resulting in a very high density of information, which in turn, leads to ambiguity and haziness.

69. "A haze rested on the low shores that ran out to sea in vanishing flatness." 
70. "It had born all the ships whose names are like jewels flashing in the night of time, from the Golden Hint returning with her round flans full of treasure, to be visited by the Queen's Highness...."

71. "The worst that could be said of him was that he did not represent his classes."

72. "All that mysterious life of the wilderness that stirs in the forest, in the jungles, in the hearts of wild men."

73. "The conquest of the earth, which mostly means the taking it away from those who have a different complexion or slightly flatter noses than ourselves, is not a pretty thing when you look at it too much."

74. "..... he began, showing in this remark the weakness of many tellers of tales who seem so often unaware of what their audience would best like to hear."

75. "But there was in it one river especially, a mighty big river, that you could you see on the map, resembling an $\underline{\text { immense snake uncoiled, with its head in the sea, its body at rest carving afar over a vast country, and its tail lost in the }}$ depths of the land."

5.8). Complex Sentences: Complex sentences are another means of ambiguity and haziness as they carry much information which may disturb the readers. The following examples illustrate this point:

76. "The great wall of vegetation, an exuberant and entangled mass of trunks, branches, leaves, boughs, festoons, motionless in the moonlight, was like a rioting invasion of soundless life, a rolling wave of plants, piled up, crested, ready to topple over the creek, to sweep every little man of us out of his little existence."

77. "Looking past that mad helmsman, who was shaking the empty rifle and yelling at the shore, I saw vague forms of men running bent double, leaping, gliding, indistinct, incomplete, and evanescent. It was the shaft of a spear that, either thrown or lunged through the opening, that caught him in the side just below the ribs."

78. "His clothes had been made of some stuff that was brown holland probably, but it was covered with patches all over, with bright patches, blue, red, and yellow, patches on the black, patches on the front, patches on elbows on knees; colored binding around his jacket, scarlet edging at the bottom of his trousers; and the sunshine made him look extremely gay and wonderfully neat withal, because you could see how beautifully all this patching had been done."

79. "The woods were unmoved, like a mask - heavy, like the closed door of a prison - They looked with their air of hidden knowledge, of patient expectation, of unapproachable silent."

80. "A quarrelsome band of footsore sulky niggers trod on the heels of the donkey; a lot of lents, campstools, in boxes, white cases, brown bales would be shot down in the courtyard, and the air of mystery would deepen a little over the muddle of the station."

5.9). Hypothetical/Conditional Sentences: Conditional sentences indicate impossibility and then darkness. Many instances of the conditional sentences (if 3) are fairly distributed throughout the novel to indicate negativism and impossibility which in tern indicate darkness.

81. "They (would have been) even more impressive, those heads on the stakes, if their faces (had not been) turned to the house."

82. "I (could have been) more disgusted if I (had travelled) all this way for the sole purpose of talking with Mr. Kurtz."

83. "If she (had offered to come) aboard I really think. I (would have tried) to shoot her."

84. "I think I (could have raised) on outcry if I (had believed) my eyes."

85. "If he (had not heard) me coming, I (would have fallen) over him, too."

The bracketed verbs in the above examples indicate the hypothetical meaning is absolute, and amounts to an implied rejection of the conditions.

\section{CONCLUSION}

In this amazing novel, Conrad provides the essentials that would capture the readers' attention. It has all the trappings of the conventional adventure tale mystery, exotic setting, suspense obscurity, murkiness and then darkness. The novel is most symbolic and ambiguous. Conrad deliberately leaves out almost people, places and times unknown as indicators of darkness.

Most importantly, the language of Heart of Darkness deviates from the everyday language, but many recurrent phrases in the novel are significant because they exploit the routine phraseology: words and grammar of the language which all indicate darkness.

An overall discourse scheme in the novel is Europe and African, the River Thames and the River Congo, light and dark, all with much commented ambiguity between these poles:

"And this (the Thames) also "said Marlow Suddenly" has been one of the dark places on the earth"

bearing in mind the title of the book and its very last phrase "the tranquil waterway (the Thames) seemed to lead into the heart of an immense darkness". stand hand in hand.

\section{REFERENCES}

[1] Achebe, C. (1988). "An Image of Africa: Racism in Conrad's Heart of Darkness", in R. Kimbrough (ed) Joseph Conrad: Heart of Darkness, pp.251-62. New York: Norton.

[2] Conrad, J. (1983). Heart of Darkness. Penguin English Library.

[3] Dutton, D.G. (2007). A review of: Journey into the Heart of Darkness. The Psychology of Genocide, Massacres, and Extreme 
Violence: Why Normal People Come to Commit Atrocities. Westport, CT: Praeger Security Internation.

[4] Greaney, M. (2002). Conrad, Language, and Narrative. Cambridge: Cambridge University Press.

[5] Haris, W. (1988). "The Frontier on which Heart of Darkness Stands in R. Kimbrough (ed.) Joseph Conrad: Heart of Darkness, critical edn, 3rd edn, in pp.262-68. New York: Norton.

[6] Kimbrough, R. (ed.) (1988). Joseph Conrad: Heart of Darkness, critical edn, 3rd edn, New York: Norton.

[7] Knowles,F.(1998). "New versus old" in Hickey, L.(ed) The Pragmatics of Translation, Clevedon (Avon), Multilingual Matters Ltd., PP. 103-13.

[8] Said, S. (1994)." Culture and Imperialism. Vintage: London.

[9] Sarvan, C.P. (1988). "Racism and Heart of Darkness" in R. Kimbrough (ed.) Joseph Conrad: Heart of Darkness, critical edn, 3rd .pp 280-85. New York: Norton.

[10] Senn, W. (1980). Conrad's Narrative Voice. Bern: Franck.

[11] Singh, F. B. (1988). "The Colonialistic Bias of Heart of Darkness", in R. Kimbrough (ed.) Joseph Conrad: Heart of Darkness, critical edn, 3rd .pp.268-80. New York: Norton.

[12] Stampfl, B. (1991). "Marlow's Rhetoric of Self-Description in Heart of Darkness" Modern Fiction Studies 37:183-96.

[13] Stubbs. M. (2003). "Conrad, concordance, collocation: Heart of Darkness or light at the end of the tunnel 〈http://:www.uni-trier.de/file admin/fb2/ANG/linguistic/stubbs-2003-Conrad-lecture.pdf〉.

[14] Stubbs. M. (2005). "Conrad in the computer: examples of quantities stylistic methods". http://lal.sagepup.com/cgi/content/abstarct/14/1/5.

[15] Watt, I. (1988). Impressionism and Symbolism in Heart of Darkness", in R. Kimbrough (ed.) Joseph Conrad: Heart of Darkness, critical edn, 3rd, in pp.311-36. New York: Norton.

[16] Zimbardo, P. (2007). The Lucifer effect: Understanding how good people turn evil. New York: Random House.

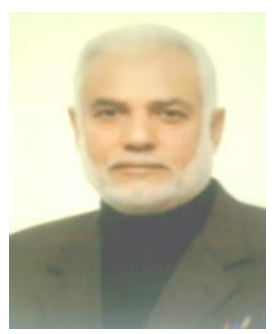

Khalil Hassan Nofal obtained his PhD from Jordan University in 2002. He occupied some educational, administrative and academic posts: School Supervisor (English), EDC, Administration Officer, and General Education Specialists/UNRWA - UNISCO. He is Editorial Board member in (IJSST) AND (EJBSS) and APETAU member. 